Canadian Journal of Higher Education Revue canadienne d'enseignement supérieur

Volume 44, No. 3, 2014, pages 68 - 85

\title{
Engaged Pedagogy and Transformative Learning in Graduate Education: A Service- Learning Case Study
}

Charles Z. Levkoe, Shauna Brail, \& Amrita Daniere University of Toronto

\begin{abstract}
Operating at the interface between ideas and action, graduate education in geography and planning has a responsibility to provide students with theoretical and practical training. This paper describes service-learning as a form of engaged pedagogy, exploring its ability to interrogate notions related to the "professional turn" and its contributions to transformative learning. Using a case study of a graduate-level service-learning course at the University of Toronto, we address the challenges associated with service-learning and highlight opportunities for students, faculty, universities, and community organizations. Our case study is based on assessment and analysis of the course and contributions to student learning, professional development, and community engagement. We contend that, at the graduate level, service-learning is an underutilized pedagogical tool. Service-learning can impart high-demand skills to graduate students by transforming how students learn and move from knowledge into ideas and ultimately action, and by offering opportunities for developing higher-order reasoning and critical thinking.
\end{abstract}

\section{Résumé}

À la frontière entre les idées et l'action, les études supérieures en géographie et en planification se doivent de fournir aux étudiants une formation à la fois théorique et pratique. Cet article décrit l'apprentissage par le service comme une forme de pédagogie engagée, tout en explorant sa capacité à 
ébranler les notions liées aux " priorités professionnelles », et en analysant ses contributions à l'apprentissage transformateur. À l'aide de l'étude de cas d'un cours d'apprentissage par le service au cycle supérieur à l'Université de Toronto, nous abordons les défis associés à l'apprentissage par le service et nous mettons l'accent sur les possibilités qui s'offrent aux étudiants, aux enseignants, aux universités et aux organismes communautaires. Notre étude de cas se fonde sur l'évaluation et l'analyse du cours en question, de même que sur ses contributions à l'apprentissage des étudiants, au perfectionnement professionnel et à l'engagement communautaire. Nous sommes d'avis que l'apprentissage par le service est un outil pédagogique sous-utilisé aux cycles supérieurs. L'apprentissage par le service peut transmettre des compétences inestimables aux étudiants des cycles supérieurs en transformant la façon d'apprendre des étudiants et en passant de l'étape des connaissances à celle des idées et éventuellement à l'action, tout en développant un niveau de raisonnement plus élevé et une réflexion critique.

Graduate education in geography, planning, and related disciplines aims to teach students to understand and act upon complex social and economic realities. This demands the development of a particular set of skills and knowledge base. Planning, in particular, operates at the interface between ideas and action (Friedmann, 1987); thus graduate education has a responsibility to provide both theoretical and practical training for students. Service-learning (SL), as a pedagogical practice, aims to unite what appear to be separate realms of theory and practice by providing the opportunity to connect academic work and community development work. Within the university context, SL courses become an educational space where students work with partner organizations on community-identified needs. As a form of experiential education, SL focuses on promoting student learning and reflection by combining community experience and classroom seminars.

We believe that graduate geography and planning courses provide an ideal pedagogical opportunity to implement SL (see also Roakes \& Norris-Tirrell, 2000). Demand is growing for students to have "practical" learning opportunities to better prepare them for the demands of potential employers (Dowling \& Ruming, 2013). This shift results from many factors, including an increasingly competitive market and both perceived and real failures of academic research to address community concerns and equip students to be socially responsible and engaged citizens upon graduation (Reardon, 1998). Experiential education opportunities, such as SL, have proliferated in universities as a way to provide more comprehensive education and training to students (Britt, 2012). As a unique form of experiential learning, SL presents the opportunities for students to gain the skills and knowledge necessary for employability while at the same time providing a valuable resource to community organizations. SL is differentiated from other forms of experiential education such as internships, field courses, and studio workshops because of the shared focus on both service and learning. Ideally, SL allows students to embrace theoretical and practical realms in collaboration with a community partner, an academic advisor, and a peer group. Through SL, students have an opportunity to challenge what is perceived to be a theory-practice divide, to contribute to an organization's mandate, to gain practical 
experience, and to reflect critically on the processes of their learning. While these benefits are well rehearsed within scholarly debate, there is a significant dearth of literature discussing the SL experience at the graduate level.

In this paper we analyze the opportunities for graduate-level SL to prepare students, as knowledgeable, skilled, and critical individuals, for future employment. We argue that graduate SL courses can provide an opportunity to both complicate the "professional turn" in community-university relations and contribute to transformative learning that provides students the skills they need to make critical decisions once they are employed professionally. We draw on the case study of Planning for Change: Community Development in Practice, a full-year graduate course at the University of Toronto in the Department of Geography and Program in Planning. Course materials, including the syllabus, student reflections, final project reports, evaluation surveys, and reflective interviews, were examined in the case study. Collectively, we draw on our personal experiences designing and teaching SL courses for nearly a decade as well as a review of SL literature. Beyond their value to graduate geography and planning departments, the arguments advanced in this paper, we believe, could support university faculty in embracing SL as a means of preparing graduate students from many disciplines for the changing world of work and playing a more active role in efforts that address social justice and promote social change.

\section{Perspectives on Service-Learning in Graduate Geography and Planning Education}

Although the definition of SL remains contested (Eyler \& Giles 1999), we follow Butin (2006), who described SL's potential as a radical and transformative pedagogy requiring "the linkage of academic coursework with community-based service" (p. 1). We also accept that there are at least three primary sets of pedagogical objectives associated with SL, as noted by Britt (2012): (a) skill-set practice and reflexivity, (b) civic values and critical citizenship, and (c) social justice activism (p. 82). Through this approach, faculty facilitates student engagement with community organizations to provide a service to the community and, in addition, to meet a series of course-based, predefined learning goals. As Butin (2010) argued, the service element of a course is analogous to an assigned text in providing the foundation for critical reflection and intellectual growth. While community service is key, the learning that results occurs most clearly through critical reflection exercises embedded into an SL course curriculum (Felten \& Clayton, 2011; Jacoby, 1996).

There are a variety of approaches to understanding SL as pedagogy. Our focus on SL in this paper is threefold. First, we contend that SL at the graduate level offers faculty, students, and community partners a distinctive opportunity for learning, engagement, skill transfer and acquisition, and critical inquiry. At the graduate level, these opportunities are facilitated, in large part because of the wider skill set, maturity, and commitment of graduate students. Second, and despite critiques related to the ethics, practices, and ideology of SL, it remains a useful, valuable pedagogy that deserves to be examined and integrated into relevant teaching and engagements, rather than abandoned because of the possibility of problematic relationships between student learning, faculty, and community partners. By acknowledging how, why, and when problematic relationships might appropriate the value of SL, and by addressing them through partnerships and course design, we can realize the potential of SL pedagogy. Third, we argue-largely on the basis of the aforemen- 
tioned approach to SL that acknowledges critiques and the role of critical inquiry while at the same time situating graduate students, faculty, and community partners in SL rolesthat SL presents the potential for transformative learning and engagement.

Because SL is embedded in both community and classroom, it is an alluring pedagogy that may offer the opportunity for transformative change: in higher education, in the ways in which students engage in learning and critical inquiry through reflection and praxis, in communities, and in the political and ideological realms of university-community relations. SL, as pedagogy, also inherently raises difficult questions for students, faculty, and community partners related to ethical, political, social, and economic problems. The answers to these questions are often discovered at a personal and professional level by means of learning and critique. We refer to these as opportunities for transformative learning in the sense that through SL pedagogy, student approaches to learning are altered in unforeseen and significant ways.

Most research about SL pedagogy focuses on undergraduate education (Logsdon \& Ford, 1998; Lu \& Lambright, 2010). This is significant because we suggest that the integration of SL into graduate courses can benefit from the advanced role that graduate students play in the community on the basis of their pre-existing knowledge, experience, commitment to continued education, and relative maturity. Lu and Lambright (2010) asserted that consideration should be given to graduate students' life and work experiences in comparison with those of undergraduates when creating SL opportunities. In particular, these differences in student profiles might alter the ways in which SL can be delivered most effectively and impactfully in the context of graduate study. At the undergraduate level, SL has been demonstrated to contribute to deep student learning, community engagement, acceptance and understanding of difference, and the promotion of students' civic engagement (Astin \& Sax, 1998; Astin, Voglegesang, Ikeda, \& Yee, 2000; Eyler \& Giles, 1999; Felten \& Clayton, 2011; Keen \& Hall, 2009). Felten and Clayton (2011) contended that SL can ultimately produce transformative outcomes in the ways students develop and produce new knowledge, particularly by enhancing the civic engagement of an educated, action-oriented individual acting as part of a broader community.

On the basis of previous findings, we posit that-when combined with the increased focus on critical inquiry, problem solving, and analytical, ethical, and reflective thinking at the graduate level- the positive benefits of SL traditionally associated with undergraduate students are amplified for graduate students. The case study presented in this paper aims to enhance understanding of the distinct potential for SL in graduate education, although we acknowledge that there is more work to be done in unpacking the nuanced opportunities that SL pedagogies may provide in enhancing transformative forms of graduate education.

Growing interest in SL has paralleled the so-called professional turn in higher education. This refers to how universities have restructured their approach to education over the past three decades to respond to pressure from governments and other funders to create qualified and employable students and strengthen the connections between employers and universities (Harris, 2004). Within SL literature, the professional turn is harnessed in three directions: professionalization and skills, civic engagement, and helping students make stronger connections between theory and application within and outside the classroom. The ways in which these streams intersect provide spaces for conflict and 
the potential for interesting work to emerge, though it ought to be acknowledged that not all SL theory or practice engages with each of these three directions. However, it is largely because of these intersections that our interest in SL as a pedagogy has emerged; and at the same time these critical junctures also inform our perspectives on how to best engage with SL while appreciating its limitations.

Research highlights the "real world" experience that SL can foster at the graduate level, including the development of career-based skills and the continued commitment to community engagement after graduation (Logsdon \& Ford, 1998; Maccio, 2011 ; McLaughlin, 2010; Wittmer, 2004). Focusing on the effectiveness of SL for graduate students in a master of public education course, Lu and Lambright (2010) concluded that time-intensive SL projects can greatly enhance students' professional skills. Furthermore, SL experience can provide graduate students the opportunity to develop potential networks and notions of how to use their advanced knowledge and skill sets outside the academic environment.

Evidence of the integration of SL, and of experiential learning more broadly as part of the professional turn, is emphasized through policy documents. For example, a report by the Council of Ontario Universities (2014) highlighted the provincial government's focus on encouraging professional skills development, emphasizing the impact that experiential learning opportunities for university students can have on future career success and economic well-being.

Despite these positive shifts, critical views of efforts designed to encourage relationships between the university and the surrounding community also persist. The fundamental underlying philosophy of a liberal education is that it opens students' minds to the wealth of ideas and disciplines needed to understand the world (Blitz, 2004). This perspective is based on the precept that a flexible, open, and well-grounded education is the best preparation for a rapidly changing society. In contrast, the professional turn has undermined the university's commitment to provide students with exposure to the greatest possible range of ideas and values (Shore, 2010) in favour of a vocational type of education (Arrowsmith, Bagoly-Simo, Finchum, Katsuhiko, \& Pawson, 2011). Some critics view SL courses emphasizing development of work-related skills as narrowing students' exposure to the theoretical and applied curriculum that normally makes up a complete liberal arts education (Gibson, 2007).

Some scholars view increases in community-based opportunities as a reflection of neoliberal logics that may have adverse effects (Catungal, 2007). Government cutbacks and privatization of services associated with neo-liberalism at the urban scale have created significant gaps, particularly in the provision of welfare services (Harvey, 2007). In some cases, student volunteers in SL placements may be taking on positions that were previously remunerated, thereby contributing to the loss of paid employment (Holdsworth \& Quinn, 2010).

Beyond the different perspectives about SL and acquisition of professional skills, other debates consider challenges surrounding higher education and outside-the-classroom experiences. For example, there has been some discussion of pedagogies that attempt to bridge the more ideological focus of SL on community development and civic engagement with the more practical focus of professional skills development. Civic professionalism reflects on the notion that for civic engagement to succeed, individuals need to move from a focus on self to a focus on community and others. Boyte and Fretz (2010) argued that 
the civic engagement movement must confront challenges of individualism, privatization, and isolation within universities and communities. By promoting the development of embedded public values, an open culture, and shared priorities, while participating in civic activities that lead to learning and skills acquisition (Boyte \& Fretz, 2010), students in courses that focus on understanding, appreciating, and supporting communities can contribute to the public good and gain valuable professional skills.

It is noteworthy that many pedagogical debates about methods of teaching and learning focus not only on the teaching and learning environment created in the classroom but also on the administrative and institutional environment at the university (Boyte \& Fretz, 2010; Butin, 2010). Despite much rhetoric that emphasizes a university's commitment to community engagement and reciprocity, efforts tend to have fallen short of promises, leading Butin (2013) to lament the superficial contributions rather than the hoped-for longlasting and rooted engagement of university faculty and students within communities.

Do the critiques of SL mean that faculty should abandon it altogether, or are there ways that SL can play a role in progressive efforts toward creating social change at the same time as SL courses place students with community partners to gain practical experience? At their core, each of the above arguments raises important questions regarding philosophical and ethical considerations associated with recent changes in higher education and their impacts. While we accept the merits inherent in these challenges to shifting modes of teaching and learning at universities, we contend that SL can and should continue to be thoughtfully utilized and refined as a valuable, integral, ethical, and actionoriented pedagogy. While there clearly remains much debate about the role of universities in imparting knowledge-as opposed to skills-to students, we suggest that SL can impart both, thereby complicating a strict focus on professional skills development and blending elements of radical, transformative change together with the professional turn in education.

At the graduate level, O'Meara (2008) makes a strong case for integrating SL as a way of supporting graduate students in their transition to becoming faculty members who are engaged as scholars and citizens, and who pursue career paths in which SL is woven into their future research and teaching. It follows, then, that SL initiatives in graduate programs present an opportunity to further amplify transformative learning. Drawing on a case study, we illustrate the way that SL, as applied in a graduate context, has the potential to challenge neo-liberal ideas about skills development and civic engagement to create opportunities for transformative learning.

\section{Planning for Change: Graduate Service-Learning in Geography and Planning}

Planning for Change: Community Development in Practice is an eight-month graduate SL course in the Department of Geography and Program in Planning at the University of Toronto. The course was taught in 2011-2012 and 2013-2014 and was open to master's and $\mathrm{PhD}$-level students in geography, planning, and other relevant graduate programs across the university. In the first year, six students were enrolled; in the second year, enrolment was at capacity, limited to 22 students because of the time and energy required

of the instructors and the space necessary for full participation by the students. Coordi- 
nated by two instructors with significant research and teaching backgrounds and experience working in the non-profit sector, graduate students worked directly with community organizations to design and implement projects. Many of the partner organizations were based in marginalized urban communities and had an explicit mandate embracing social justice (see Appendix A). In-class seminars were composed of readings, films, discussions, workshops, writing, reflections, assignments, presentations, and the completion of a major project (see Appendix B). Through critical engagement with theoretical concepts and community-based projects, students had opportunities to reflect critically on their own experiences in the context of their community-based research and work.

The first class meetings were structured as informational sessions, where the community partners made short presentations about their organizations and provided suggestions about potential projects. The intention was for the projects to be co-developed according to the needs of the particular communities and the specific skills or research interests of the students. The students were given the opportunity to select which partners they most wanted to work with, and each participated in a formal interview process led by the instructors to discuss relevant skills and interests. Throughout the course, regularly held seminars utilized a variety of pedagogical tools that engaged with core concepts of SL and social justice. Reflection pieces were submitted on an ongoing basis in a variety of forms including essays, poetry, drawings, and photographs. The seminars were also a space for regular check-ins, updates, and reflection about the SL placements. When challenges arose, there was opportunity for collective debriefing and discussion. The instructors maintained regular contact with community partners to support communication and involved them in ongoing course development.

Since projects take time and negotiation to develop, there can be confusion in the early months of the course as to the nature of the student's relationship with the community organizations. To address this, each student submitted an informal memorandum of understanding (MOU). Although formal contracts were signed between the instructors and the community organizations in advance, developing the MOUs was a way for the students to articulate their understanding of how the partnership would take shape. The community partners were invited to read the MOUs as a way to initiate dialogue and maintain open communication. In the third month, the students prepared project proposals and work plans that articulated the projects they were co-developing. During the sixth month, students submitted progress reports, and at the end of the seventh month, students made final presentations that summarized their projects. In the concluding month of the course, students submitted their final reports, which took various forms depending on the community organization's needs. Students worked closely with the instructors and community partners to ensure that their final projects met academic requirements and the needs of the community organization.

Student progress in the course was assessed as part of a mutual learning process. Evaluation was used as an additional reflection tool for learning. At various points, students were asked to complete self-evaluations around specific themes of their work, such as communication with their community partners. The partners also provided feedback to instructors and students on these same themes. Drawing on the full range of feedback and on the quality of assignments, participation, and final projects, the instructors jointly determined the final grade. 


\section{Methods and Analysis}

The assessment and evaluation of the course in this paper are based on analysis of qualitative and quantitative data collected between June 2011 and April 2014. Data were gathered from four primary sources. First, students provided written and oral evaluations about the course at class meetings, which helped the instructors to identify challenges and make changes to the curriculum as needed. Students also provided formal mid-term and final evaluations of their own work and their relationships with the community partners. In addition, the final class meeting consisted of an open discussion along with the completion of conventional and anonymous departmental evaluations to provide formal feedback on the course and the instructors. Second, instructors evaluated and analyzed formal submissions from the students, which included written reflections, assignments, project proposals and work plans, progress reports and presentations, and the final products. Instructors also held regular meetings to reflect on the course's overall progression, the projects, and student-community partner relations. We took extensive notes at these meetings and analyzed them for this paper. Third, we solicited regular feedback from community partners that provided evaluative information about the course and the role of particular students. Comments focused on students' communication, reliability, and quality of contribution, and on the quality of the final products. Community partners also commented on the overall value of the partnership. Finally, a third-party researcher was hired to interview selected students and community partners in order to gather objective feedback about their experiences. The authors reviewed and analyzed data from the four sources and identified major themes on the basis of apparent and latent content. The findings from these assessments are presented in the form of quotes, commentary, and general reflections.

\section{Complicating Conventions}

In developing the course, we were aware of the critical literature about SL, but we did not intend to confront it so directly. As the course progressed, we were surprised by our observations of the projects being developed and by the quality of reflective discussions between students and community partners. We became aware that working with graduate students in Planning for Change was different than our previous experiences with SL at the undergraduate level and different than what was described in the literature. Drawing on these reflections and an analysis of the four data sources, this section explores new opportunities for graduate-level SL to complicate the professional turn and create opportunities for transformative learning.

Two central goals of Planning for Change are to respond to the perceived need to build mutually beneficial relationships between communities and the university; and to contribute to professionalization and skills development, enhance civic engagement, and provide opportunities for experiential learning. As a consequence, the course design emphasizes a wide range of skills rooted in social justice. Many students said that they had learned much more than they expected. As documented elsewhere, graduate-level students in geography and planning often seek out employment skills and practical experience (Dowling \& Ruming, 2013). In Planning for Change, it was not at first obvious to students that working with a non-profit organization in a marginalized neighbourhood would provide a useful experience. Many students told us that they originally chose the 
class in order to enhance their resumés and increase their job prospects after graduation. However, by the end of the course, most students described the skills and knowledge they had acquired in unexpected ways. For example, students spoke in class in a nuanced manner about structural inequality and systemic barriers faced in marginalized communities. Upon reflection, one student commented,

My biggest learning from this experience came from being outside of my comfort zone. I have been used to being a student in an academic setting. And then all of a sudden I was thrown into a situation where... there are actual needs to be met. Working with [the community partner] really gave me a different perspective about what was going on in the world.

Another student wrote,

I felt like we talked about the idea of praxis in the fall as being an ideal. For example, we talk about theory and then actually trying to connect that with our experiences going on in the community. But I think that we actually accomplished that. ... And my work with [the community partner] could actually make a significant contribution even though there are broader changes that still need to happen in terms of advocacy work and political change. It's a tangible and important step, even if it's a baby step.

Some students found that their projects required them to utilize new research methods and translate technical findings into plain-language documents-an important skill that has the potential to benefit future employability and build links between theory and practice. Wilson et al. (2013), in their examination of how to transform teaching and acquisition of professional skills for graduate and undergraduate students, explicitly focused on the problem of moving away from a generic, mechanized approach to skills development and developing instead a process that is sophisticated and meaningful. Our findings demonstrate that the SL experience enabled graduate students to develop sophisticated and meaningful professional skills as an unanticipated (though pedagogically purposeful) outcome of SL experiences. These skills were not developed through a traditional rote approach, but were instead acquired by students as part of what they foresaw as an unexpected but professionally relevant effect of their SL participation.

By requiring students to actively engage in determining the specifics of their projects and the content of some in-class seminars, the course used an unfamiliar pedagogy that initially made some of the students uncomfortable. Students also struggled with the messy process of collaborative, community-based work. For example, in contrast to the outlines of traditional courses, the syllabus of Planning for Change was frequently modified on the basis of student evaluations and feedback. In the early months, placements were fraught with ambiguity. As they mentioned frequently in class and in reflections, students did not have complete control over their projects and needed to negotiate with community partners and instructors regularly. Both instructors and students needed to be flexible about course content and SL initiatives. While these realities were initially expressed as problems, over time, students recognized the value of collaboration. One student commented, 
Being involved in a collaborative work dynamic with [my community partner], I learned a lot about how to collaborate, not just how to do it, but... that research becomes more valuable when you're doing it with other people.

Students spoke of "deep" learning that related knowledge and application of theoretical ideas to everyday practice. One student commented,

[I learned a lot from] thinking about the readings at the beginning of the course that talked about the structures and limitations of non-profit organizations, but also seeing them as a space where really innovative things can happen. And when I went to do my placement, I saw that this was actually happening in practice.

As graduate students, the participants all brought both hard and soft skills to their placements and had opportunities to develop skills. For example, hard skills that students applied included the use of GIS (geographic information system) mapping technologies, specific computer skills, graphic design, writing, and policy analysis. The varied soft skills that students possessed included experience working with community groups, communication, facilitating dialogue, giving feedback, cooperating as team members, solving problems, contributing in meetings, and conflict resolution. For example, the Community Food Mapping and Village of Storytellers initiatives (see Appendix A) necessitated that students learn about a specific community and a part of the city they had never visited-a key formative experience for many professions. At the same time, one student was able to apply GIS skills in a different context, and the community partner obtained access to urban street-level expertise. The university resources and the data were used in a way that would not have been feasible otherwise.

As graduate students, many came to the SL projects with specific skill sets, experiences, and background knowledge. Since projects were determined collaboratively, they involved a set of skills unique to each individual student. As a result, the work they provided had not previously been available to the community partners. In one project, a student working with an organization aiming to impact policy noted, "I already had some skills that were beneficial to doing this kind of work... because I used to work at the City." As an integrated part of a community organization, students played a key role in creating the infrastructure for progressive environments that could work more effectively against the neo-liberal agenda. At the same time, discussion during in-class sessions used scholarly articles to engage students in critical debates about the origins and impacts of neoliberalism and the contextualized meanings of social justice. By working collaboratively with organizations involved in social-justice-related advocacy and organizing, rather than strictly service provisioning or charity work, this course contributed significantly, we suggest, to social change efforts.

In sum, students in Planning for Change gained valuable skills that enhanced their employability. In addition to honing and improving knowledge, the course gave them exposure to a wide range of literatures, an unfamiliar pedagogy, diverse communities, and organizations in areas of the city with which they were unfamiliar. The course provided all participants with opportunities to build close personal connections.

The course projects drew on students' existing knowledge and skills and linked experiential learning with theoretical readings and in-class reflection. In this way, the course ap- 
proached learning as praxis. Students learned about the theoretical and practical realities of community development, planning, research and methodology, writing (professional and academic), interacting in a professional working environment, communication, finding a balance between independence and teamwork, and the importance of providing clear and practical recommendations to community partners. Through in-class seminars, readings, group discussions, presentations, assignments, and reflections, students made direct connections between theoretical and practical learning. This approach also created spaces for critical reflection. For example, some of the in-class discussions focused on issues such as the role of graduate education, positionality in the process of developing and completing projects, issues of social justice, and the political and economic context of the non-profit sector. Reflecting on the classes, one student commented, "The readings really got me thinking about a lot of the values that I have personally and how my positionality affects my research. I've never thought about it that way so it really got me thinking more introspectively." In discussion, another student noted, "The readings and class discussions on pedagogical strategies provided a knowledge base while the ongoing reflections and assignments ensured course objectives linked to my experiences."

Practical skills, as we note above, are highly valued by graduate students-particularly in the current period of employment uncertainty. Student reflection pieces and feedback about the course made clear that they valued the experience of being asked to do work that made a concrete difference for community partners. Feedback from community partners made it clear that students were, in most cases, asked to deliver materials that the organizations actually used to advance their efforts. This is evident from the following comments of two community partners:

I was excited for the opportunity to work with a placement student that had some experience under their belt to assist with the work. Although most placement students can learn to be very helpful, I often find myself micro-managing and hand holding with younger students. It's refreshing to collaborate with a student that can provide feedback, critical thinking and has a better understanding of the way things work. There should be a different term for this [kind of a service-learning placement compared with] most placement students that come in with little to no experience.

The final project was of extremely high quality. I am impressed by how much information and data [the student] managed to gather, much of which would have been difficult to find. Her analysis was also informative and thoughtful, taking into consideration multiple perspectives.

The unusual attributes of Planning for Change resonated with participants in remarkable ways. The longer time frame of the course and graduate students' skills enabled them to engage in work within the communities that would not have been possible in a one-semester course. Partners explicitly expressed their appreciation of the eight-month commitment in our post-course survey. Students had sufficient time to develop projects, understand the organization and community context, and see projects through from conception to completion. Having more time permitted us to achieve multiple goals beyond those required by the academic institution and the professional needs of employers- 
goals such as employment skills, community development, and civic engagement. In an environment where most courses are one term long, the flexibility to offer a full-year course at the graduate level contributed in important ways to the sustained involvement of students and partners.

Through SL, students in the course were able to address our community partners' needs and expectations. The community partners' feedback unanimously expressed that participating in the course was positive and beneficial for them. Many partners commented that their experiences with graduate students surpassed their expectations, which had been based on previous experience with student placements. They described the students as committed, professional, enthusiastic, reliable, and independent, and they benefited from the way students took on leadership roles. One partner wrote, "This was one of the most successful university-community placement opportunities that we have pursued since [our organization's] inception." Such comments reflect the success with which students integrated into organizations and worked with staff and community members, as well as the high quality of work they completed. In almost all cases, the projects made substantial contributions to partner organizations and the broader community. Feedback from community partners such as "[The student's] work was integral to the development and overall outcome of our broader project" were quite typical. In all cases, community partners described student-written final reports as useful, professional, and high-quality.

\section{Conclusions}

Planning for Change has evolved in response to what we have learned from teaching the course and conducting evaluations with students and community partners. We have modified the course structure and revised the syllabus on the basis of participant feedback. We also redesigned the critical reflective exercises to consist of more authentic work, following suggestions from, for example, Ash and Clayton (2009). Finally, in response to student feedback, we added readings and devoted time to address quantitative and qualitative methodologies. While all students have exposure to the subject of research methods, several students needed more practical information about how to actually conduct qualitative field research. We find that using actual examples from the placements greatly helps to reinforce learning about the value and application of methods in the classroom.

It must be noted that mounting Planning for Change required altering many accepted norms in our university's institutional practices. For example, as instructors, we needed to develop a new course using an unfamiliar pedagogy. This required the creation of partnerships outside of academia, a daunting undertaking for many professors. The extra work required to set up this type of course, design the syllabus, and meet regularly with students is significant (and, in our experience, over and above the typical workload for leading graduate seminars). Establishing relationships with community partners and maintaining regular communication, before, during, and after the course, also require an extension of university instructors beyond their traditional setting. Furthermore, many graduate programs would find freeing up the requisite faculty time, given current budgetary pressures, difficult to justify. Certainly, in this instance, one instructor had to essentially donate time from an already full schedule in order to demonstrate that the course deserved a place in the curriculum. 
In this paper we have argued that, in spite of theoretical and practical challenges associated with developing and teaching an SL course at the graduate level in a department of geography and planning, there are many benefits to be gained. We do not intend to suggest that mounting such a course is unproblematic. Yet challenges to the traditional classroom structure and pedagogy in graduate education can be resolved by university administration, faculty, and students together through careful design of curriculum and course requirements.

It is important to question the value and role that SL plays in higher education, as this enriches debates about how and whether to implement SL initiatives elsewhere. As Nairn (2005) reminded us, thinking critically about experience is an important part of implementing any pedagogy. Just as we would question the conduct of more passive forms of learning and research activities, the SL techniques, methods, and outcomes deserve the same close inspection. We believe that the graduate SL course benefited as a result of our awareness of criticisms and the efforts that were made to mitigate these through course design. Most importantly, the strategic crafting and implementation of the course allowed us to interrogate some of the conventional criticisms of SL courses in a way that both responds to positive aspects of the professional turn in higher education and contributes to transformative learning among students, community partners, and instructors. Benefits similar to these are likely to accrue to students in a wide variety of graduate programs.

After reflection on Planning for Change as a case study, we suggest that graduate-level SL opportunities can greatly enhance geography and planning education, and graduate education more generally. Most significantly, this engaged pedagogy can contribute to the development of students' employability, and it presents a number of other direct and indirect benefits such as increasing students' critical reflexivity, civic values, critical citizenship, and social justice activism. Graduate-level SL can enhance the development of student, faculty, university, and community interactions and capacity in a progressive and transformative manner. On the basis of this case study, we suggest that service-learning, when implemented thoughtfully, can present potential for deep, interactive, and lasting learning that connects theory to practice and leads graduates to become knowledgeable, engaged citizens.

\section{References}

Arrowsmith, C., Bagoly-Simo, P., Finchum, A., Katsuhiko, O., \& Pawson, E. (2011). Student employability and its implications for geography curricula and learning practices. Journal of Geography in Higher Education, 35(3), 365-377.

Ash, S. L., \& Clayton, P. H. (2009). Generating, deepening, and documenting learning: The power of critical reflection in applied learning. Journal of Applied Learning in Higher Education, 1, 25-48.

Astin, A. W., \& Sax, L. J. (1998). How undergraduates are affected by service participation. Journal of College Student Development, 39(3), 251-263.

Astin, A.W., Voglegesang, L. J., Ikeda, E. K., \& Yee, J. A. (2000). How service learning affects students. Los Angeles: University of California, Higher Education Research Institute. 
Blitz, M. (2004). Liberal education and liberalism. Good Society, 13(3), 45-48.

Boyte, H. C., \& Fretz, E. (2010). Civic professionalism. Journal of Higher Education Outreach and Engagement, 14(2), 67-89.

Britt, L. (2012). Why we use service-learning: A report outlining a typology of three approaches to this form of communication practice. Communication Education, 61(1), $80-88$.

Butin, D. (2006). Future directions for service learning in higher education. International Journal of Teaching and Learning in Higher Education, 18(1), 1-4.

Butin, D. (2010). Service-learning in theory and practice: The future of community engagement in higher education. New York, NY: Palgrave.

Butin, D. (2013). Does community engagement have a place in a placeless university? New England Journal of Higher Education, March 25. Retrieved from http://www. nebhe.org/thejournal/

Catungal, J. P. (2007). The 'ivory tower' in the neoliberal city: Towards a critical geography of university-community relationships (MA thesis). University of Toronto, Toronto.

Council of Ontario Universities. (2014). Bringing life to learning at Ontario universities. Retrieved from http://cou.on.ca/publications/reports/pdfs/march262014--experiential-learning-report

Dowling, R., \& Ruming, K. (2013). Synergies between geography, planning and vocationalism in curriculum development and implementation. Journal of Geography in Higher Education, 37(2), 204-219.

Eyler, J., \& Giles, D. (1999). Where's the learning in service-learning? San Francisco, CA: Jossey-Bass.

Felten, P., \& Clayton, P. (2011). Service-learning. New Directions in Teaching and Learning, 128, 75-83.

Friedmann, J. (1987). Planning in the public domain: From knowledge to action. Princeton, NJ: Princeton University Press.

Gibson, C. (2007). Geography in higher education in Australia. Journal of Geography in Higher Education, 31(1), 97-119.

Harris, N. (2004). Experiential learning in built environment education. Centre for Education in the Built Environment (CEBE) Transactions, 1(1), 3-7.

Harvey, D. (2007). A brief history of neoliberalism. New York, NY: Oxford University Press.

Holdsworth, C., \& Quinn, J. (2010). Student volunteering in English higher education. Studies in Higher Education, 35(1), 113-127.

Jacoby, B. (1996). Service-learning in higher education. San Francisco, CA: John Wiley and Sons.

Keen, C., \& Hall, K. (2009). Engaging with difference matters: Longitudinal student co-curricular service-learning programs. Journal of Higher Education, 8o(1), 59-79. 
Logsdon, C., \& Ford, D. (1998). Service-learning for graduate students. Nurse Educator, 23(2), 34-37.

Lu, Y., \& Lambright, K. (2010). Looking beyond the undergraduate classroom: Factors influencing service learning's effectiveness at improving graduate students' professional skills. College Teaching, 58(4), 118-126.

Maccio, E. (2011). Graduate social work students' attitudes toward service-learning. Journal of Teaching in Social Work, 31(2),163-177.

McLaughlin, E. (2010). The "real-world" experience: Students' perspectives on servicelearning projects. American Journal of Business Education, 3(7), 109-117.

Nairn, K. (2005). The problems of utilizing 'direct experience' in geography education. Journal of Geography in Higher Education, 29(2), 293-309.

O'Meara, K. (2008). Graduate education and community engagement. New Directions for Teaching and Learning, 113, 27-42.

Reardon, K. (1998). Enhancing the capacity of community-based organizations in East St. Louis. Journal of Planning Education and Research, 17(4), 323-333.

Roakes, S., \& Norris-Tirrell, D. (2000). Community service learning in planning education: A framework for course development. Journal of Planning Education and Research, 20(1), 100-110.

Shore, C. (2010). Beyond the multiversity: Neoliberalism and the rise of the schizophrenic university. Social Anthropology, 18(1), 15-29.

Wilson, A., Akerlind, G., Walsh, B., Stevens, B., Turner, B., \& Shield, A. (2013). Making 'professionalism' meaningful to students in higher education. Studies in Higher Education, 38(8), 1222-1238.

Wittmer, D. (2004). Business and community: Integrating service learning in graduate business education. Journal of Business Ethics, 51(4), 359-371.

\section{Acknowledgements}

The authors gratefully appreciate the patience and perseverance of the students and community partners who have made Planning for Change: Community Development in Practice possible over successive years. Their dedicated efforts and thoughtful reflections and feedback provided the substance for this paper. We would like to thank Jessica Nelligan for helping to design the original course; Paul Hess for his ongoing support; and Lisa Chambers, Rebecca Wolf, and Ben Liu from the University of Toronto's Centre for Community Partnerships for ongoing encouragement and insight into teaching and learning about community-campus engagement. We also acknowledge financial and inspirational support from the Social Sciences and Humanities Research Council Partnership project Community First: Impacts of Community Engagement. Finally, we are thankful for feedback and editorial support from the editors, especially Sara Carpenter, as well as the anonymous reviewers. 


\section{Contact Information}

Charles Z. Levkoe holds a postdoctoral fellowship at Wilfrid Laurier University. His interdisciplinary teaching, research, and publishing bridge the fields of political and social geography, urban policy, and environmental sustainability. Levkoe is the academic co-lead on Community First: Impacts of Community Engagement (CFICE): Community Food Security Hub, a major cross-Canada partnership initiative investigating how community campus partnerships can be designed and implemented to maximize the value created for non-profit, community-based organizations.

Shauna Brail is director of experiential learning and a senior lecturer at the University of Toronto, Urban Studies Program. Her research focuses on urban transformation, economic development and creative industries, and the pedagogy of experiential learning. She also develops and manages relationships with multiple organizations and stakeholders as part of the Urban Studies Program's experiential learning initiatives. Over the past 10 years she has placed more than 450 undergraduate students in internships and service-learning placements with organizations across the city.

Amrita Daniere is a professor in the Department of Geography and Program in Planning at the University of Toronto. Her research focuses on environmental issues facing lowincome communities in cities of the global South. Daniere is also a devotee of servicelearning and teaches a graduate course based on working with organizations and agencies in the Toronto. 
Appendix A. Sample Student Projects

\begin{tabular}{|c|c|}
\hline Partner Organization & Description of Project \\
\hline Greenbelt Foundation & $\begin{array}{l}\text { The Broader Public Sector Investment Fund Project-Stu- } \\
\text { dents contributed toward a report to the provincial govern- } \\
\text { ment regarding food service in the public sector along with } \\
\text { barriers and recommendations for increasing local food } \\
\text { procurement. }\end{array}$ \\
\hline Centre for Social Innovation & $\begin{array}{l}\text { Replicating and Sustaining Co-Working Models-Students } \\
\text { explored ways to support non-profit organizations in the pur- } \\
\text { chasing of real estate to be used for new co-working spaces. }\end{array}$ \\
\hline $\begin{array}{l}\text { Toronto Public Space } \\
\text { Initiative }\end{array}$ & $\begin{array}{l}\text { Design Review Panel-Students supported research to } \\
\text { strengthen the Design Review Panel in Toronto by studying } \\
\text { the rationale and implementation of design review, analyz- } \\
\text { ing the inside story, discussing the challenges, and proposing } \\
\text { solutions to the identified problems. }\end{array}$ \\
\hline $\begin{array}{l}\text { Malvern Action for } \\
\text { Neighbourhood Change }\end{array}$ & $\begin{array}{l}\text { Community Food Mapping-Students supported an initiative } \\
\text { to provide a visual representation of food initiatives currently } \\
\text { taking place in the Malvern neighbourhood. The project was } \\
\text { to create two maps: a GIS food asset map that included the } \\
\text { location of local access points and initiatives; and a series of } \\
\text { community food maps highlighting resources available to } \\
\text { community members and challenges to accessing food. }\end{array}$ \\
\hline iTaxiworkers Association & $\begin{array}{l}\text { Toronto Taxicab Industry Review - In 2011, the City of } \\
\text { Toronto launched a comprehensive Taxicab Industry Review } \\
\text { with the aim of resolving persistent industry problems. As } \\
\text { a primary stakeholder in this review, the iTaxiworkers have } \\
\text { been preparing a list of proposed reforms to submit to the } \\
\text { city. Students were involved in research activities undertaken } \\
\text { to support these proposed reforms, including comparative } \\
\text { research on taxi industries in other North American cities. }\end{array}$ \\
\hline Storytelling Toronto & $\begin{array}{l}\text { Village of Storytellers Initiative-Students conducted inter- } \\
\text { views and focus groups with storytellers in Regent Park to } \\
\text { evaluate the impact of the project at the individual and com- } \\
\text { munity level. The project also involved documentation and } \\
\text { analysis of the initiative's challenges and benefits and mak- } \\
\text { ing recommendations for new storytelling initiatives in other } \\
\text { places. }\end{array}$ \\
\hline $\begin{array}{l}\text { Sustain Ontario: The Alliance } \\
\text { for Healthy Food and Farming }\end{array}$ & $\begin{array}{l}\text { Leveraging Best Practices in Municipal Local Food Procure- } \\
\text { ment-Students conducted a jurisdictional scan of policies } \\
\text { and practices in the United States, the United Kingdom, and } \\
\text { Canada to generate a report outlining the opportunities for } \\
\text { municipal local food procurement. }\end{array}$ \\
\hline
\end{tabular}




\section{Appendix B. Summary of Major Course Components}

\begin{tabular}{|c|c|}
\hline September & $\begin{array}{l}\text { - } \text { Informational meeting with community partners } \\
\text { - } \quad \text { Student interviews for service-learning placement } \\
\text { - } \quad \text { Begin service-learning placements } \\
\text { - } \quad \text { In-class sessions }\end{array}$ \\
\hline October & $\begin{array}{ll}\text { - } & \text { In-class sessions } \\
\text { - } & \text { Diversity and inclusivity training } \\
\text { - } & \text { Reflection assignments } \\
\text { - } & \text { Memorandum of understanding assignment } \\
\end{array}$ \\
\hline November & $\begin{array}{ll}\text { - } & \text { In-class sessions } \\
\text { - } & \text { Reflection assignments } \\
\text { - } & \text { Project proposal and work plan } \\
\end{array}$ \\
\hline December & - Community partner and student mid-year evaluations \\
\hline January & $\begin{array}{ll} & \text { In-class sessions (organized/facilitated by students) } \\
\text { - } & \text { Reflection assignments } \\
\end{array}$ \\
\hline February & $\begin{array}{ll}\text { - In-class sessions (organized/facilitated by students) } \\
\text { - } \quad \text { Reflection assignments } \\
\text { - } \quad \text { Progress reports }\end{array}$ \\
\hline March & $\begin{array}{ll}\text { - In-class sessions (organized/facilitated by students) } \\
\text { - } \quad \text { Final oral presentations with community partners and guests }\end{array}$ \\
\hline April & $\begin{array}{l}\text { - } \quad \text { Final reports } \\
\text { - } \quad \text { Final community partner and student evaluations } \\
\text { - } \quad \text { Final debrief and discussion }\end{array}$ \\
\hline
\end{tabular}

